\title{
Distribution of the burrows of Bufo fernandezae (Anura, Bufonidae) outside of the breeding season
}

\author{
Sergio Daniel Rosset and Leandro Alcalde \\ Instituto de Limnología “Dr. Raúl A. Ringuelet” (ILPLA), Casilla de Correo 712 (1900) La Plata, Buenos Aires, \\ Argentina. E-mail: rosset@ilpla.edu.ar.
}

\begin{abstract}
Distribution of the burrows of Bufo fernandezae (Anura, Bufonidae) outside of the breeding season. We studied the spatial distribution of a population of adult Bufo fernandezae based on the spatial arrangement of their burrows. The study was carried out in a suburban area near La Plata, Argentina. Two sampling methods were used: counts of burrows on areas of known size (quadrat sampling) and distance measures (plotless sampling). Data obtained using both methods indicate that the spatial distribution in the analyzed population is at random. In agreement with one of the assumptions of random distributions, burrow density was not significantly correlated with distance to water bodies, soil hardness and vegetation cover at the studied spatial scale. Respect to the other assumption of random distributions, we did not obtain data to assess it independently. Positive interactions such as aggregations to avoid water loss described for others species of Bufo do not occur in B. fernandezae because toads of this species solve this problem living in individual burrows. Negative interactions such as territoriality were not evident herein probably because at the population density found ( 1 individual by $83 \mathrm{~m}^{2}$ ) competition by resources decreases. We emphasize the utility of the methods used here to apply in future works that need to obtain data about the response of $B$. fernandezae's populations exposed to different environmental conditions.
\end{abstract}

Keywords: Anura, Bufonidae, Bufo fernandezae, spatial distribution, burrows, Argentina.

\section{Introduction}

The geographic range of a species and the abundance of organisms within this range can shift in response to changing environmental conditions (Brown and Lomolino 1998). At the local level, organisms use microhabitats and

Received 4 June 2004.

Accepted 9 November 2004.

Distributed December 2004. experience environmental variation similar to, but on a much smaller scale than geographic variations (Cox and Moore 2000). Organisms also interact with one another, and this can place constraints on patterns of abundance and distribution on both geographic and local scales (Cox and Moore 2000). In adult anurans, most local studies concern to the habitat use during the breeding season (e.g., Wells 1977, Shepard 2002), but few of them have investigated the habitat use outside of the breeding season 
(Regosin et al. 2003, Shepard 2004). Anurans are ectotherms, and have a permeable skin, as consequence they are susceptible to conditions of the terrestrial environments, such as moisture and temperature which can affect their distribution and habitat use (Duellman and Trueb 1986, Smith et al. 2003). Nevertheless, they possess different behavioral, morphological and physiological adaptations to avoid water loss (e.g., burrowing behavior) (Duellman and Trueb 1986, Stebbins and Cohen 1995).

The common lesser toad, Bufo fernandezae, is distributed throughout northeastern Argentina, southern Paraguay, Uruguay, and southeastern Brazil (Frost 2004). Adults of B. fernandezae live in burrows they dig, which can reduce water loss and provide protection against predators and fires (Gallardo 1957, 1969). When rainfall is intense, B. fernandezae digs its burrow in the mud using lateral and alternate movements of hindlimbs (Gallardo 1969, Gallardo and Varela de Olmedo 1992). According to Gallardo (1957, 1969), B. fernandezae is highly sedentary and spends most of the time in its burrow, leaving only for feeding or breeding. A typical burrow is inhabited by only one toad, has an oval opening ranging from $3.5^{\prime} 2.5 \mathrm{~cm}$ to $4.5^{\prime} 3.5 \mathrm{~cm}$, and has a depth equivalent to three times the snoutvent length of the inhabitant toad (Gallardo 1969, 1974).

The fact that Bufo fernandezae is a sedentary toad that lives in burrows makes it an ideal species to study the distribution of adult toads outside of the breeding season and to analyze the relation between the spatial arrangement and some local environmental conditions such as distance to water bodies, soil hardness and vegetation cover.

\section{Materials and Methods}

\section{Study Area}

The study was carried out at Los Porteños (34 $\left.53^{\circ} \mathrm{S}, 58^{\circ} 05^{\prime} \mathrm{W}\right)$, a suburban area about 10 km NW of La Plata, Buenos Aires province,
Argentina. The study area is situated in the Oriental District of the Pampean Phytogeographic Province corresponding to the Chacoan Domain (Cabrera 1971). Land uses include cattle ranching, floriculture and horticulture. We made observations in a pasture ( 1 ha) surrounded by two small paths, a Eucalyptus forest and a grassland with cattle grazing. The site was used for horticulture until five years ago when it was abandoned. Vegetation consists mainly of annual herbaceous such as Stipa spp., Bromus spp., Paspalum spp., Avena spp., Briza spp., Cyperus spp., Juncus spp., Trifolium spp., Taraxacum spp., Cirsium spp., Sonchus spp., and Baccharis spp. There are two water bodies where B. fernandezae breeds: a semi-permanent shallow pond of $11^{\prime} 7 \mathrm{~m}(10-50 \mathrm{~cm}$ depth $)$ and a temporary ditch of $100^{\prime} 0.5 \mathrm{~m}(10 \mathrm{~cm}$ depth).

\section{Field Activities}

The study was carried out during August and September 2002, just before the breeding season of Bufo fernandezae. In order to examine the spatial distribution of toads, we sampled their burrows using quadrat methods and plotless methods (Pielou 1969, Rabinovich 1980, Krebs 1999). For both methods we used three circular plots of 3, 7 and $14 \mathrm{~m}$ diameter arbitrarily defined in order to avoid the effect of size in estimations of spatial distribution. The plots were placed concentrically to a point chosen by a random number table and using the fence line posts surrounding the study site as a system of coordinates. A total of 34 samples for each plot size were taken. For the quadrat samples we counted the number of $B$. fernandezae burrows inside each size of plots employed. For the plotless samples we measured the distance between a random point and the nearest burrow $(P B)$ and the distance between this burrow and the nearest neighboring burrow $(B B)$. All measures were taken into the biggest plots (14 $\mathrm{m}$ diameter) using a measuring tape (to the nearest $1 \mathrm{~cm}$ ) to $10 \mathrm{~cm}$ of the ground. 


\section{Data Analysis}

On quadrat samples data, we employed the number of burrows to calculate the index variance to mean ratio $(\mathrm{V} / \mathrm{m})$ for each plot size (Pielou 1969, Krebs 1999). If $V / m<1$ the distribution is uniform, if $V / m=1$ it is at random, and if $V / m>1$ it is aggregated. Significant deviations of $V / m$ from 1 were evaluated using the expression $X^{2}=V / m(n-1)$ which follows a two-tailed chi-squared distribution with $n$-1 degrees of freedom ( $a=0.05)$, being $n$ the number of samples (Krebs 1999). The adjustment to the corresponding probabilistic model (Poisson, Positive Binomial, Negative Binomial) was evaluated using the test $G$ of goodness of fit (Sokal and Rohlf 1979, Krebs 1999).

On plotless samples data, we employed distance measures to calculate the coefficient of aggregation of Hopkins-Skellam $\left(A=S P B^{2} /\right.$ $S B B^{2}$ ) (Hopkins 1954, Pielou 1969). If $A=1$ the spatial distribution is at random, if $A>1$ it is aggregated and if $A<1$ it is uniform. Significant deviations of $A$ from 1 were evaluated using the expression $X=|x-0.5| 20 \overline{(2 n+1)}$, which follows a normal distribution with $n$ degrees of freedom ( $\mathrm{a}=0.05)$, being $x=A /(1+A)$, and $n$ the number of pairs of observations (Hopkins 1954, Pielou 1969).

The distance to water bodies was measured from the central point of each plot to the border of the nearest water bodies (pond or ditch), using a measuring tape (to nearest $1 \mathrm{~cm}$ ). Soil hardness was measured five times at random within each $14 \mathrm{~m}$ plot. The soil was penetrated applying $20 \mathrm{~kg} / \mathrm{cm}^{2}$ upon an iron bar of $30 \mathrm{~cm}$ length. Soil hardness was estimated as the length of the bar that was buried. Soil hardness measurements were taken immediately after an intense rainfall $(100 \mathrm{~mm})$ because toads dig their burrows during intense rains (Gallardo 1969, Gallardo and Varela de Olmedo 1992). Vegetation cover was measured five times at random within each $14 \mathrm{~m}$ plot using a rectangle divided in six equal parts that represent different values of vegetation cover: 0 (without vegetation), 20, 40, 60, 80, and 100\% (all covered). The association among distance to water bodies, soil hardness, vegetation cover and number of burrows by plot was evaluated using Pearson's correlation coefficient $(r)$.

\section{Results}

We found 4, 17 and 63 burrows on plots of 3,7 and $14 \mathrm{~m}$ diameter, respectively. It is important to remark that we found only one toad by burrow. The estimated population density was 0.012 toads $/ \mathrm{m}^{2}$. In all sizes of plots used, the index variance to mean ratio did not differ significantly from 1 , as consequence, the spatial distribution of the studied population was at random (Table 1). The data of number of burrows for each plot size were adjusted to the Poisson's model and no significant differences

Table 1 - Number of burrows of Bufo fernandezae, descriptive statistics, index $V / m$, significant test $\left(X^{2}\right)$, and the adjustment to the Poisson's model $(G)$ of each plot size $(\mathrm{N}=34)$.

\begin{tabular}{lccc}
\hline PLOT DIAMETER $(\mathrm{m})$ & $\mathbf{3}$ & $\mathbf{7}$ & $\mathbf{1 4}$ \\
\hline Number of burrows & 4 & 17 & 63 \\
Mean & 0.12 & 0.50 & 1.85 \\
Variance & 0.11 & 0.38 & 2.37 \\
$V / m$ & 0.92 & 0.76 & 1.28 \\
$X^{2}$ & $30.03(\mathrm{df}=33, \mathrm{p}>0.05)$ & $25.08(\mathrm{df}=33, \mathrm{p}>0.05)$ & $42.24(\mathrm{df}=33, \mathrm{p}>0.05)$ \\
$G$ & $0.684(\mathrm{df}=1, \mathrm{p}>0.05)$ & $1.897(\mathrm{df}=2, \mathrm{p}>0.05)$ & $8.807(\mathrm{df}=5, \mathrm{p}>0.05)$ \\
\hline
\end{tabular}


between the observed and expected frequencies were found (Table 1).

Nineteen of the $14 \mathrm{~m}$ plots had at least two burrows, as consequence, the spatial distribution was estimated by the coefficient of aggregation of Hopkins-Skellam. This coefficient did not differ significantly from 1 indicating that the spatial distribution was at random $(\mathrm{A}=0.69 ; \mathrm{X}$ $=1.16 ; \mathrm{df}=19 ; \mathrm{p}>0.05$ ).

There were no association between the number of burrows and the analyzed environmental conditions. The number of burrows found in a plot was not correlated with the distance to water bodies. The Pearson's correlation coefficient was $r=-0.11(\mathrm{p}=0.54)$ for distances to pond and $r=0.23(\mathrm{p}=0.19)$ for distances to ditch. Distances to pond ranged from 14.5 to $103 \mathrm{~m}(\bar{x}=61.84$; $\mathrm{SD}=24.74 ; \mathrm{N}$ =34). Distances to ditch ranged from 8.3 to $96.3 \mathrm{~m}(\bar{x}=48.49 ; \mathrm{SD}=26.51 ; \mathrm{N}=34)$. The number of burrows was not correlated to the soil hardness of the plot (Pearson $r=0.09 ; \mathrm{p}=$ 0.59). Soil hardness ranged from 6 to $18.5 \mathrm{~cm}$ $(\bar{x}=14.37 ; \mathrm{SD}=2.9 ; \mathrm{N}=34)$. The number of burrows was not correlated to vegetation cover in a plot (Pearson $r=0.24 ; \mathrm{p}=0.27$ ). Vegetation cover ranged from 24 to $92 \%$ ( $\bar{x}=57.45 ; \mathrm{SD}=$ 20.49, $\mathrm{N}=34$ ).

\section{Discussion}

Classically, three kinds of population's spatial distribution are recognized: random, aggregated and uniform (Brown and Orians 1970, Krebs 1999). Our results indicate that the burrows of adult Bufo fernandezae are distributed at random relative to other burrows in the studied population. This means that the presence of one individual neither raises nor lowers the probability that another individual will appear nearby (Pielou 1969, Brown and Orians 1970, Rabinovich 1980, Krebs 1999).

In addition, the distribution of burrows was not correlated with soil hardness, vegetation cover, or distance to water bodies; factors that would be directly affecting burrow construction and protection, and breeding respectively. These data indicate that individuals are able to dig burrows throughout the study site.

According to Pielou (1969) and Rabinovich (1980) random distributions are related to nonheterogeneous environmental conditions and non-significant interactions among conspecific organisms. The fact that we did not find association among the analyzed environmental conditions and the number of burrows is consistent with the first assumption of random distributions. Respect to the second assumption, we did not obtain data to assess independently the interactions among individuals. If some kind of positive (e.g., feeding groups) or negative (e.g., territoriality) interaction takes place outside of the breeding season, the pattern found by us should be not at random.

Individuals of some species of Bufo aggregated when do not breed as a behavioral adaptation to avoid water loss (Duellman and Trueb 1986). This behavior does not occur in $B$. fernandezae who solves this problem living in individual burrows (Gallardo 1957, 1969).

Territoriality in anurans is characterized by resource limitation, site tenacity, and resource defense (Mathis et al. 1995). Shepard (2002) studied the habitat used by males of Rana clamitans and found that territoriality manifests only in situations of high population density. In spite of the marked site tenacity of B. fernandezae who spends most of the time in its burrow (Gallardo 1969), territoriality was not evidenced in the studied population probably because at the population density found ( 1 individual by 83 $\mathrm{m}^{2}$ ), competition by resources decreases and sings of territoriality become inexistent.

Finally, we emphasize the utility of the methods used here to apply in future works that need to obtain data about the response of $B$. fernandezae populations exposed to different environmental conditions.

\section{Acknowledgements}

We wish to thank to A. I. Kehr, R. J. 
Lombardo, J. Muzón, and two anonymous reviewers for helpful suggestions on earlier versions of the manuscript. To G. Finarelli and L. Sanchez for helping us in the fieldwork. The present work constitutes the Scientific Contribution $\mathrm{N}^{\mathrm{o}} 743$ of the Instituto de Limnología "Dr. Raúl A. Ringuelet”.

\section{References}

Brown, J. H. and M. V. Lomolino. 1998. Biogeography. Sunderland, Massachusetts. Sinauer Associates. 691 pp.

Brown, J. L. and G. H. Orians. 1970. Spacing patterns in mobile animals. Annual Review of Ecology and Systematics 1: 239-262.

Cabrera, A. L. 1971. Fitogeografía de la República Argentina. Boletín de la Sociedad Argentina de Botánica 14: $1-39$.

Cox, C. B. and P. D. Moore. 2000. Biogeography - an ecological and evolutionary approach. London. Blackwell Science. 298 pp.

Duellman, W. E. and L. Trueb. 1986. Biology of Amphibians. Baltimore and London. McGraw-Hill. 670 pp.

Frost, D. R. (ed.). 2004. Amphibian Species of the World - an online reference. URL: http://research.amnh.org/ herpetology/amphibia/index.php. Captured on 1 October 2004.

Gallardo, J. M. 1957. Las subespecies argentinas de Bufo granulosus Spix. Revista del Museo Argentino de Ciencias Naturales "Bernardino Rivadavia", Ciencias Zoológicas 3: 337-374.

Gallardo, J. M. 1969. La distribución de las subespecies de Bufo granulosus Spix: su fidelidad a los sistemas hidrográficos Sudamericanos. Ciencia e Investigación 25: 406-416.

Gallardo, J. M. 1974. Anfibios de los Alrededores de Buenos Aires. Buenos Aires. Editorial Universitaria de Buenos Aires. 231 pp.

Gallardo, J. M. and E. Varela de Olmedo. 1992. Anfibios de la República Argentina: ecología y comportamiento. Fauna de Agua Dulce de la República Argentina 41: $1-116$.

Hopkins, B. 1954. A new method for determining the type of distribution of plants individuals. Annals of Botany, London, N. S. 18: 213-227.

Krebs, C. J. 1999. Ecological Methodology. Menlo Park, California. Benjamin Cummings. 654 pp.

Mathis, A., R. G. Jaeger, W. H. Keen, P. K. Ducey, S. C. Walls, and B. W. Buchanan. 1995. Aggression and territoriality by salamanders and a comparison with the territorial behavior of frogs. Pp. 633-676 in $\mathrm{H}$. Heatwole and B. K. Sullivan (eds.), Amphibian Biology - social behavior. Australia. Surrey Beatty and Sons.

Pielou, E. C. 1969. An Introduction to Mathematical Ecology. New York. Wiley-Interscience. 286 pp.

Rabinovich, J. E. 1980. Introducción a la Ecología de Poblaciones Animales. México. Compañía Editorial Continental. $313 \mathrm{pp}$.

Regosin, J. V., B. S. Windmiller and J. M. Reed. 2003. Terrestrial habitat use and winter densities of the wood frog (Rana sylvatica). Journal of Herpetology 37: 390-394.

Shepard, D. B. 2002. Spatial relationships of male green frogs (Rana clamitans) throughout the activity season. American Midland Naturalist 148: 394-400.

Shepard, D. B. 2004. Seasonal differences in aggression and site tenacity in male green frogs, Rana clamitans. Copeia 2004: 159-164.

Smith, G. R., A. Todd, J. E. Rettig, and F. Nelson. 2003. Microhabitat selection by northern cricket frog (Acris crepitans) along a west-central Missouri creek: field and experimental observations. Journal of Herpetology 37: 383-385.

Sokal, R. R. and F. J. Rohlf. 1979. Biometría - principios y métodos estadísticos en la investigación biológica. Madrid. Blume Ediciones. 832 pp.

Stebbins, R. C. and N. W. Cohen. 1995. A Natural History of Amphibians. Princeton, New Jersey. Princeton University Press. 316 pp.

Wells, K. D. 1977. The social behaviour of anuran amphibians. Animal Behaviour 25: 666-693. 